\title{
DIABETIC KETOSIS COMPLICATED BY ACUTE RENAL FAILURE
}

\author{
A. L. Linton, M.B.(Edin.), M.R.C.P.(Glasg.), M.R.C.P.(Edin.) \\ A. C. KenNedy, M.D.(Glasg.), M.R.C.P.(Glasg.), F.R.C.P.(Edin.) \\ From the Artificial Kidney Unit, Glasgow Royal Infirmary
}

A DEGREE of nitrogen retention is the rule in diabetic ketosis (Lyall and Anderson 1932) but despite this there are very few reported cases in which the uræmia has become clinically important nor has the pathogenesis of this change been fully elucidated. Aoyama and Kolff (1958) have reported a case of diabetic coma in which hæmodialysis was used first to correct the acidosis and on a second occasion a few days later to combat the electrolyte upset of associated acute renal failure. A similar case, treated with hæmodialysis, has been described by Lasch (1960). Other cases of acute renal failure complicating diabetic ketosis are on record (Gastineau, 1959; Chao, 1959) but most were of mild degree and responded to conservative treatment. Parsons (1959) mentions diabetic ketosis as a cause of acute renal failure, but gives no details.

The present case of diabetic ketosis complicated by acute renal failure is reported for several reasons. Since there are few such cases on record, it is important to draw attention to renal function in diabetic ketosis; failure to recognize the development of renal complications might be disastrous. The combination of renal failure and diabetic ketosis presents a complex electrolyte upset, the management of which requires very careful thought. This case demonstrates that hæmodialysis can offer a speedy solution to such problems, and indeed it may be the only satisfactory answer to electrolyte upsets of this kind.

\section{Case Report}

The patient was a female, aged 6r years, with diabetes of 30 years' standing, which was previously well controlled on 36 units of soluble insulin daily, in divided doses. On July 3 , I $96 \mathrm{I}$, she developed profuse diarrhœea and was admitted to the Victoria Infirmary, Glasgow. Severe diabetic ketosis was found to be present, and she was in coma, with the blood pressure unrecordable for several hours. Blood sugar was $1,400 \mathrm{mg}$./ $100 \mathrm{ml}$.; Na4I mEq./l, K 5.I mEq./1 and $\mathrm{HCO}_{3} 7 \mathrm{mMol} / \mathrm{ll}$. I Blood urea was $150 \mathrm{mg}$./ $/ 100 \mathrm{ml}$., this being attributed to dehydration.

She was treated with the usual regime of massive doses of insulin intravenously and intramuscularly, with large amounts of intravenous saline and glucose. Potassium supplements were given the next day, and she appeared to improve. It was noted that after the first day the blood-sugar levels were extremely labile, and that the urine volume failed to rise even after rehydration was complete. This pattern persisted until July 10, 196r, at which time the daily urine volume had fallen to less than $200 \mathrm{ml} . / 24$ hours. Serum $\mathrm{Na} 133 \mathrm{mEq} . / 1, \mathrm{~K} 4.2 \mathrm{mEq} . / 1$ and urea $340 \mathrm{mg} . / \mathrm{r} 00 \mathrm{ml}$. The acidosis had been corrected, but the blood sugar varied from $30 \mathrm{mg} . / 100 \mathrm{ml}$. to $600 \mathrm{mg}$./100 ml. withif a few hours.

On July II, I96I, the patient was transferred to the Artificial Kidney Unit, Glasgow Royal Infirmary? On admission her general state was very poor. Physicad examination revealed mental confusion, considerable sacral odema and hypotension (B.P. 90/50 mm. HgD Scattered moist sounds were heard throughout the chest. There was mild diabetic retinopathy, but no evidence of neuropathy.

Investigations: Blood sugar $417 \mathrm{mg}$. $/ 100 \mathrm{ml}$; $\mathrm{Na}$ $134 \mathrm{mEq} . / 1, \mathrm{~K} 6.8 \mathrm{mEq} . / 1, \mathrm{HCO}_{3} 30 \mathrm{mMol} / \mathrm{l}$; bloo\& urea $350 \mathrm{mg} . / 100 \mathrm{ml}$. Urine volume $300 \mathrm{ml} . / 24$ hoursis it contained no sugar, a moderate amount o里 protein, occasional red cells and hyaline casts. Urinary urea $0.56 \mathrm{~g} . / 100 \mathrm{ml}$., PCV $36 \%$.

A diagnosis of acute oliguric renal failure was made, based upon the high blood urea and the poor urine volume and concentration. It was uncertain whether this was superimposed on chronic diabetic nephro $\underline{\Phi}$ pathy, although scrutiny of the notes made at theo diabetic clinic which the patient attended revealed previous albuminuria, hypertension or renal symptoms. It was therefore assumed that at least part of damage was acute, and potentially reversible. Althoug the daily rise in blood urea was relatively slow $(20 \mathrm{mg}$ 㱟 $100 \mathrm{ml}$./day), and the daily urine volume was slowl improving, the serum potassium was rising quickly, she was overhydrated and control of blood-sugar levels was difficult. The final and overriding indication for imme diate hæmodialysis was provided by her very poos clinical condition.

Hæmodialysis was undertaken on July II, $196 \frac{2}{7}$ using a modified rotating drum machine of the Kolffe Brigham type with a high efficiency (Kennedy, Gray Dinwoodie and Linton, 1961). The dialysing fluig used was of standard composition with regard to electrolytes. Normally, with this machine, glucose is added to the dialysing fluid to a concentration of $32 \%$. $\mathrm{mg} / \mathrm{/} / 00 \mathrm{ml}$., in order to compensate for the osmotig pressure of the plasma proteins. In this case, where the patient's blood sugar was $417 \mathrm{mg}$./ $100 \mathrm{ml}$., this effect would have been lost and further overhydration might have occurred. The bath glucose concentratiot was therefore doubled. An arterio-venous circuit wa used, and a flow rate of $150 \mathrm{ml}$./min. was obtained onl with the assistance of L-noradrenaline, the patient $\mathrm{O}$ blood pressure remaining very low. Aggravation of the hypotension led to the procedure being discontinued after three hours. The clinical condition of the patients was unchanged, but the serum potassium had been reduced to normal and the blood urea lowered to $160 \mathrm{mg}$. $/ 100 \mathrm{ml}$.

The patient's further progress is shown in Fig. On the day following hæmodialysis her condition w\& much improved. Diuresis had begun, and her diabetee was well controlled on four-hourly doses of soluble insulin. The usual conservative regime of dietary an fluid restriction was enforced, and recovery was typica 
of that seen in resolving acute renal failure due to acute tubular necrosis. Blood urea rose again for a few days in the early diuretic phase, then levelled off and began to fall. Features of note in the rccovery phase were that the urine sugar content continued to be no guide to the blood-sugar levels, the continued hypotension and the recurrence of diarrhœa: She required continuous L-noradrenaline for four days after dialysis, and no cause for this hypotension was found. ECG showed no evidence of myocardial infarction. Stool cultures were repeatedly negative for pathogens, and the diarrhœa, too, remained unexplained.

Six days after dialysis (July 17, 1961) the patient was well enough to be returned to the Victoria Infirmary. The blood urea was $150 \mathrm{mg} . / 100 \mathrm{ml}$. and falling; daily urine volume was in excess of 2.51 ., with a urea concentration of $0.67 \mathrm{~g} . / 100 \mathrm{ml}$; the serum electrolytes were all normal. From then on, so far as renal function was concerned, progress was good. The blood urea was less than $40 \mathrm{mg} . / 100 \mathrm{ml}$. after four weeks, and did not rise again. Electrolyte and fluid balance remained completely normal. It had been intended to readmit her for assessment of renal function, but further unexplained diarrhœa and eventually alimentary bleeding prevented this. Comprehensive investigation revealed no cause for this, and the patient died on November 19, 1961. Postmortem examination showed only severe atrophy of the colonic wall, and it was thought that nonspecific colitis was the cause of the bleeding. There was no evidence of cerebrovascular or cardiac disease, and the adrenals were normal. The kidneys showed some tubular atrophy with increase in interstitial tissue consistent with recovery from acute tubular necrosis. The glomeruli showed little change.

There seems little doubt that her death was unrelated to her episode of ketosis, and that she had made a good recovery from the superimposed acute renal failure, with restoration of adequate renal function.

\section{Discussion}

There are few reports in the literature of acute renal failure complicating diabetic ketosis. However, closer study of papers dealing with series of patients in diabetic coma suggests that renal damage of some degree is probably not uncommon. For example, Cohen, Vance, Runyan and Hurwitz (1960) report 73 cases of diabetic acidosis, with four deaths. Acute renal failure was prominent as a contributory cause in two of the four fatal cases, and temporary oliguria and azotæmia were present in a third. Trever and Cluff (1958) reviewed 476 cases of diabetic ketosis, and found 24 cases where increasing azotæmia was observed; of these, $2 \mathrm{r}$ were found to have infection or chronic renal disease, but in three there was no obvious cause beyond the ketosis. There remains an appreciable mortality in diabetic ketosis, and it seems possible that at least some of this is due to acute renal damage, often superimposed on chronic renal disease. It is also possible that some cases of azotæmia complicating diabetic ketosis are not recognized, for the finding of an elevated blood urea may be ascribed to dehydration. It seems reasonable to suggest that closer supervision of renal function during and after diabetic ketosis is desirable.

The cause of acute renal failure in diabetic ketosis is difficult to decide, since many possible factors are present in such a complex electrolyte

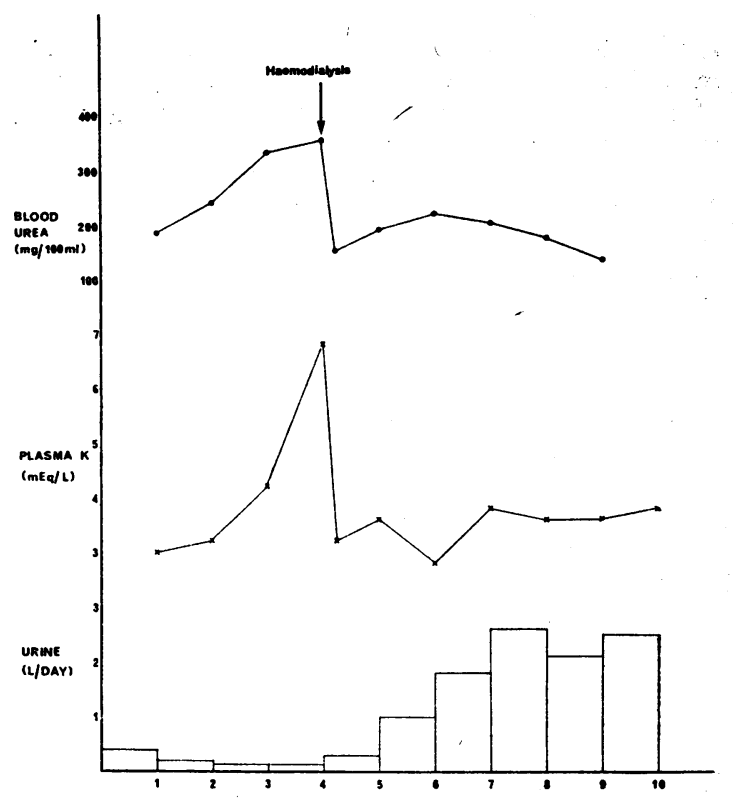

oars

FIG. I.

upset. Hypotension offers an ætiology common to many other types of acute renal failure, but acidosis and hypokalæmia may also play a part in damaging the tubules. Various disturbances of renal function have been reported during and after diabetic ketosis. It has been suggested that the azotæmia of diabetic ketosis is more usually due to renal disturbance than to dehydration, and a marked fall in RBF, RPF, GFR and urea clearance has been demonstrated during diabetic ketosis (Reubi, 1953). In most cases, PAH extraction values showed no evidence of renal vasoconstriction, but this did appear occasionally and the patient developed a true tubular necrosis. Bernstein, Foley and Hoffman (1952) performed clearance studies in six patients with diabetic coma - they demonstrated a reduction of $\mathrm{C}_{\mathrm{M}}, \mathrm{C}_{\mathrm{pah}}$, and $\mathrm{Tm}_{\mathrm{pah}}$, but all these values returned to normal on correction of dehydration and electrolyte upsets. In contrast, two other patients showed progressive azotæmia and reduction in the above values, suggesting that mild tubular necrosis had occurred. It has been suggested that hypotension is the essential causative feature of this renal upset (Knowles and Alverson, 1956) but Shields (1958) reports a case of ketosis causing acute renal failure in which there was no hypotension, but severe hypokalæmia. There is other evidence that hypokalæmia may be important in the tubular damage in the demonstration of both glomerular and tubular damage following a phase of hypokalæmia (Relman and Schwartz, 1956). It should also be pointed out that serum potassium levels in diabetic ketosis are no indication of total body potassium-radioactive studies have shown a loss of one-third of the total body potassium with a serum 
level of $8 \mathrm{mEq}$./1. (Holler, 1946). Finally, acidosis may also be involved in the renal damage which is often present, though only occasionally progressing to the stage of requiring specific therapy.

Our findings in this case throw no light on the causation of the acute renal failure, since hypotension, hypokalæmia and acidosis were all present. It does, however, serve to highlight some points of general management. Close watch should be kept on the blood urea and the urine output in diabetic ketosis. Should azotæmia develop, then it is unsafe to assume that this is due to dehydration or to chronic diabetic nephropathy, and the patient should be given the benefit of the doubt with adequate treatment, including hæmodialysis if necessary. This procedure will give time for more precise diagnosis which might be obtainable only by renal biopsy. In the presence of severe renal damage, it is well to remember that urinary sugar content is no guide to the blood levels. It seems also that blood sugar levels are extremely labile $\vec{Q}$ when acute renal failure complicates diabetio ketosis, and this may be due to the fact that nos sugar is being excreted. Finally, the electrolyte upset due to diabetic ketosis complicated by acute renal failure is extremely severe, and it is probable that hæmodialysis offers the best hope of successfu $\sqrt{5}$ treatment.

\section{Summary}

A case of acute renal failure complicating diabetie ketosis is reported. The number of similar cases previously described is small, but review of severatlarge series of patients with diabetic ketosis suggests that some renal damage is common. This case serves to draw attention to the need for carefub watch on renal function in diabetic ketosis, andg demonstrates that hæmodialysis may be invaluable in management of such cases.

\section{REFERENCES}

Aoyama, S., and Kolff, W. J. (1958): Severe Diabetic Acidosis Treated With the Artificial Kidney, $\mathcal{F}$. Amer. medঙ Ass., 166, 9.

Bernstein, L. M., Foley, E. F., and Hoffman, W. S. (1952): Renal Function During and After Diabetic Coma F. clin. Invest., 31, $7 \mathrm{I} 1$.

ChaO K'Uei TAN (1959): Diabetic Coma Complicated by Renal Failure: A Case Report with Renal Biopsy, Chin F. int. Med., 7, 259 .

Cohen, A. S., VANCE, V. K., Runyan, J. W., and Hurwitz, D. (1960): Diabetic Acidosis: An Evaluation of the Cause $\overrightarrow{0}$ Course and Therapy of 73 Cases, Ann. intern. Med., 52, 55 .

Gastineau, C. F. (1959): Diabetic Acidosis Complicated by Acute Renal Failure, Minn. Med., 42, ro73.

Holler, J. W. (1946): Potassium Deficiency Occurring During Therapy of Diabetic Acidosis, $\mathscr{F}$. Amer. med. A

KenNEDy, A. C., Gray, M. J. B., Dinwoodie, A., and Linton, A. L. (196r): Removal of Urea, Creatinine, Ữ Acid and Inorganic Phosphate by a Rotating Drum Artificial Kidney, Lancet, ii, 996.

Knowles, H. C., and Alverson, G. (1956): The Osmotic Activity of the Renal Tubule in Diabetic Acidosis, F. Lab clin. Med., 48, 176.

LASCH, F. (1960): Successful Hæmodialysis in Acute Renal Failure Due to Diabetic Coma, Wien klin. Wschr., 72, 509

Lyall, A., and AnDerson, A. G. (1932): Diabetic Coma: The Significance of Alterations in Blood Urea, Quart. $\mathcal{J}_{\bar{\sigma}}$ Med., i, 353 .

Parsons, F. M. (1958): Hæmodialysis: Indications and Results, Postgrad. med. F., $35,625$.

Relman, A. S., and Schwartz, W. B. (1956): The Nephropathy of Potassium Depletion, New Engl. F. Med., 255, 1950

Reubi, F. C. (1953): Glomerular Filtration Rate, Renal Blood Flow and Blood Viscosity During and After Diabetic Coma, Circulat. Res., r, 410.

ShIElds, C. E. (1958): Diabetic Acidosis With Transient Renal Insufficiency, U.S. armed Forces med. F., 9, 1351. 3

Trever R. W., and Cluff, E. L. (1958): The Problem of Increasing Azotæmia During Management of Diabetic Acidosis, Amer. F. Med., 24, 368 . 